\title{
Educational leadership from a philosophical and Islamic perspective
}

\author{
Muhammad Nasri Dini \\ Pascasarjana IAIN Surakarta, Indonesia. \\ elnasri.ahmad@gmail.com
}

DOI: $10.18326 /$ attarbiyah.v5i2.105-121

$\begin{array}{ccc}\text { Submitted: } & \text { Accepted: } & \text { Published: } \\ \text { 23 October 2020 } & \text { 5 January 2021 } & \text { 8 January 2021 }\end{array}$

\begin{abstract}
An educational leader must comprehend educational leadership theory to perform good leadership. A lot of educational practitioners have not understood yet. What does educational leadership mean? How does philosophical and Islamic view see educational leadership? This research aims at explaining them to society mainly for those who contribute to Islamic institutions by applying a library research approach, moreover for the source of data the author takes documentation in form of a notebook, journal article, and other written data or documents. Based on the philosophical view, educational leadership shall suit ontology, epistemology, and axiology theories. The varieties of philosophical leadership are coming from Plato, Aristoteles, and Machiavelli. While in the Islamic view, the leader requires to have prophet Muhammad's characters, for instance: sidiq/honest; amanah/trustworthy; tabligh/communicative; and fathonah/intelligent.
\end{abstract}

Keywords: Educational leadership, Islamic Perspective, Philosophy 


\section{INTRODUCTION}

The leadership issue is a very interesting and never-ending subject to talk about. Because it is one of the most important factors that will determine the success or failure of an organization in achieving the final goals it wants to achieve(Sukamto, 1999). A leader will be held accountable for what he leads, whether in this world by interested parties, either from members of the organization he leads or also from his superiors structurally in the organization. And later on in the last day a leader will appear and be asked by Allah Almighty as the last responsibility of the leadership he has carried out during his lifetime.

Every human being is a leader, even though in a small scope, even in the smallest space he must also be a leader for himself so that the life he lives has a clear direction and purpose (Djunaedi, 2005). One of the duties of a human being is that he has a burden on his shoulders that he must carry, something that was previously offered to other creatures of Allah (the heavens, the earth, and the mountains), but all of them objected and could not accept it. Humans also become leaders of themselves, their(Bakar, 2014).

In an institution, institution, or organization, a leader is needed who can protect his subordinates. This nurturing leadership is certainly needed so that all work program implementation processes to be achieved can be carried out properly and directed by existing goals and have been programmed beforehand. This includes what happens in the field of education, talking about leadership issues, of course, requires a professional figure to be able to influence and motivate others (Srinadila, 2019).

In the case of educational institutions, other people who must be influenced and motivated, of course, are educators and education personnel at the educational institution, so that the goals and hopes to be achieved can be implemented jointly by the members of the educational institution or school. Because of the importance of this leadership issue, we often encounter various types of events containing leadership training activities, both aimed at individual participants and in groups which in the future are prepared to become good leaders for an organization or institution.

Even after a leader takes office and takes charge of leadership, there are still similar activities, be it education or training which aims to strengthen the ability of participants in terms of organizational leadership. Because it is certainly very understandable that if any organization of any kind will need and have a top leader (top leader) and/or top manager (top manager) who must carry out leadership and management functions in the institution or organization he leads. 
Based on the above description, this simple paper will try to explore the nature of educational leadership from a philosophical and Islamic perspective from literacy sources related to it. Leadership models of several philosophical figures were also put forward to more easily describe the philosophy of leadership. In the Islamic perspective, in particular, the writer can take references from the sources from Al-Qur'an and Hadith to be used as a reference or basis in building concepts related to educational leadership which is also discussed in this paper.

This paper will also try to explain the relationship between philosophy, Islam, and educational leadership in terms of ontological, epistemological, and axiological aspects. With an adequate understanding of the aforementioned matters, every individual human being, especially those who are in a position as leader of an organization, or who are preparing to occupy a leadership position will achieve comprehensive and optimal goals and results from the continuity of his leadership process. In detail and systematically the author will discuss the above problems in the following paper.

\section{METHOD}

The research method used by the author in the preparation of this paper is qualitative. The reason for choosing the research type in this paper is because the in-depth understanding of a problem in qualitative research methods is more emphasized than looking at problems for generalization research (Siyoto, 2015). Moleong as cited by Siyoto (2015) said that the data used as a source in a qualitative study is data that is displayed in the form of spoken or written words which are then analyzed by the researcher, as well as objects that can be observed in detail so that they can be revealed. the various meanings implied in the document or thing.

The author uses a literature approach or literature review (library research). Namely looking for answers to the problems that are being faced by examining various kinds of theories from literature sources that are relevant to the problems to be studied. The method used in the literature review research process is carried out by searching, selecting, collecting, processing, and concluding, and presenting data from library sources using certain techniques. 
Sugiyono, as quoted by Sari, said that the data sources in the literature review research were references and other scientific literature related to the problems to be studied (Sari \& Asmendri, 2020). This literature study researcher can simultaneously utilize the literature source as a source of data in his research, without having to conduct direct research in the field (Yaniawati \& Indrawan, 2014). By conveying this research approach, it is hoped that the next steps will be taken and the focus to be achieved in this research will become clearer.

The data presented in this study is in the form of words that need to be processed to be more concise and systematic (Muhadjir, 1998). Data collection carried out in this study is to collect library sources, both journals, books, articles, and various other writings that are relevant to themes of leadership, education and philosophy, as well as Islamic leadership and Islamic education. After that, it is sorted, presented, and continued with analysis and processed systematically.

\section{RESULTS AND DISCUSSION}

\section{Leadership}

Leadership can be interpreted as a way of leading or things about leaders. So, in the word leadership contains two main things contained in it, namely: leaders who are positioned as subjects and those who are led who are positioned as objects. Because the study of leadership is in the concept of the relationship between one human and another (Syafaruddin \& Asrul, 2015).

Whereas terminologically, leadership is an ability that a person has in terms of moving, directing, influencing, and carrying out orders to others to achieve specific goals that are expected together in an organization (Prasetyo, 2017). In line with Prasetyo, Priyono and Marnis (2018) also revealed that leadership (leadership) is an activity carried out to influence people so that they voluntarily want to work together to achieve the desired goals together.

Thoha (in Badu \& Djafri, 2017) stated that leadership is an activity that aims to influence the behavior of others, or the art of influencing human behavior, both individuals and groups. Leadership can only be carried out by a leader, that is, someone who has special expertise in the field of leadership, sufficient ability to influence the views 
of others and change the opinion of another person or group of people without having to ask first about the reasons behind it. A leader is someone who is required to be able to actively make various kinds of programs, and plans, then coordinate, conduct experiments and lead work to achieve common goals(Thaib, 2016).

From some of these definitions, the understanding can be drawn that leadership has at least three things that must be done, namely: moving, directing and influencing others, namely people who are within the scope of the organization, to do something, or vice versa do not do something in to achieve it. organizational goals that have been set together. Among the skills that must be possessed by a leader are briefly expressed in three ways, namely: technical skills, human relations skills, and conceptual skills (Syafaruddin \& Asrul, 2015). These three skills absolutely must be possessed by a leader so that the leadership he carries out can run effectively and efficiently to achieve the desired goals.

The issue of leadership in recent times has become a very significant issue to discuss (Djunaedi, 2005). Because this is very closely related to the success of an organization at any level. In Islam, the simplest indicator of a leader's success can be seen from the extent to which the application of the mandate attached to leadership can be carried out with a professional spirit and high integrity. This means that if professionalism and integrity are not found in a leader, then he is not a successful leader.

\section{Educational Leadership}

Education is a process of guidance carried out by adults to children who are still entering the stage of development so that a child can develop optimally towards maturity later (Syafaruddin \& Asrul, 2015). Education can also be defined as all kinds of efforts made by a human being to be able to cultivate and develop innate potentials, both about matters relating to body and spirit by the values that exist in society and culture (Syafaruddin \& Asrul, 2015). Education can also be defined as all kinds of efforts made by a human being to be able to cultivate and develop innate potentials, both about matters relating to body and spirit by the values that exist in society and culture(Anwar, 2017).

Education is a process carried out to develop and pass down the values and norms that exist in a society to the next generation. Because of this education, civilization will always exist and be sustainable in human life if the educational process continues as it 
should. Only with a good educational process, a person will be able to attain knowledge of what rights and obligations he must carry out as a human being, whether in his position as an individual, or relation to other people in society, or even related to his relationship to Allah Almighty.

In terms of education, leadership is also needed. It must be well understood that the implementation of educational tasks is that some serve as leaders and carry out leadership functions. He is a person who can cooperate with other people and vice versa other people can work together with him (Khamdani, 2014). On the one hand, in educational leadership, there are roles and efforts related to the success of the education and learning process, and on the other hand, it must also be understood that educational leadership also has a very close relationship with activities carried out in the context of developing education as a type of science with all branches and supporting sciences (Yusnadi, 2016). One of the functions of educators in educational institutions is a managerial function, namely to lead and control, both to himself in particular, to his colleagues and subordinates in the organization, as well as to students and society in general as consumers (Hidayat \& Nasution, 2016). Although in the context of educational institutions or schools, educational leadership can be interpreted specifically as being held by the school principal/madrasah principal. Namely, someone who is given the task and authority legally and formally to lead an educational institution (school $/ \mathrm{madrasah}$ ) in an organizational structure, where the educational institution organizes an educational process (learning and teaching).

By mobilizing all personnel (educators and education personnel) in the school, a school principal is fully responsible for the success of the education process that is being carried out(Efendi, 2017). The principal is an important part of a school. He is one of the core determinants of the quality of education in schools (Purwanto, 2019). The school principal has full authority to carry out duties and functions as a leader in a school If the leader has the right leadership skills and leadership skills, then the team he builds and runs, in this case, the organization in educational institutions/schools will run effectively (Pusat Pembinaan, 2019). 
Conversely, if the leader does not have adequate leadership skills, then the school organization will not be able to run effectively and produce maximum results as well. Particularly in its mission of carrying out success in the world of education, leadership can briefly be interpreted by the efforts of the principal in leading, influencing, and providing guidance to educators and education personnel in the schools he leads so that the educational and teaching goals that have been planned can be achieved through a series of activities that have been planned (Fatonah, 2013).

\section{Educational leadership from a philosophical perspective}

Philosophy is an explanation in the form of a basic concept which contains studies of various kinds of phenomena that occur in human life and thought critically and thoroughly (Nursikin, 2016). In language, the word philosophy comes from Arabic, namely "falsafah", this word has a root word from Greek, namely"Philosophia", philos (love), and shopia (knowledge, wisdom). If interpreted as a whole, the word philosophia can mean love of wisdom or love of knowledge.

Philosophy starts with curiosity and doubt. The characteristics of philosophical thinking are comprehensive so that a person will never be satisfied just because he already knows science from the point of view of science itself, but he always arises a desire to see the nature of that knowledge in other concentrations of knowledge. This philosophical way of thinking will be able to reach the future of mankind in the forms of ideology (Amka, 2019). As the mother of all sciences, philosophy consists of various special sciences that have been continuously developing until now(Amirudin, 2013).

Based on the ever-evolving structure of science, the scope of philosophy is divided into three areas, namely: 1) Systemic philosophy, consisting of; metaphysics, epistemology, methodology, logic, ethics, and aesthetics; 2) special philosophy, consisting of; philosophy of art, culture, education, language, history, character, politics, religion, life, and philosophy of values; and 3) scientific philosophy, consisting of; philosophy of science, psychology, and social science. The emergence and development of various leadership theories are interesting to discuss when viewed from the perspective of the philosophy of science, namely: 1) ontology, material and formal objects seen from a leadership; 2) epistemology, how the theory is developed; and 3) axiology, its benefits in application to organizations (Riyadiningsih, 2016). 
Philosophy describes all kinds of basic assumptions of every branch of science. Likewise, with education. Each field of science has its philosophical foundation. And the essential elements in the philosophical foundation all include three main things, namely: the ontological basis, the epistemological basis, and the axiological foundation (Rukiyati \& Purwastuti, 2015). In the process of forming a leader, philosophy as a science that emphasizes critical, rational attitudes, and the formation of a strong character is one of the most important factors(Wattimena, 2012).

Next will be discussed further the problem of educational leadership from a philosophical perspective. So that a leader in the field of education has a strong foundation to carry out his leadership. First, ontology. The scope of this philosophy seeks to find the essence or essence of each object which includes all reality in all its forms (Amka, 2019). He will never stop at discussing what is visible from an object, but he will also discuss what is contained in that object, namely what is concrete/material and what is abstract/spiritual.

The spirit of leadership is a potential that must be in every human being. This has been proven throughout history. In a community, there needs to be one person who is the leader if you do not want the community to become extinct. If we look at this leadership ontology further with an Islamic perspective, it will be found that universally a human being is certainly given by Allah the ability in the field of leadership, because a human being has been gifted with what is called -khalifah fil ardh- (leader on earth) (Mushowwifin, 2020).

Ontologically, the existence of this leader is very necessary for the sustainability of an organization, including educational organizations. So that organizational goals can be achieved. Not only school principals and their representatives must realize that they are a leader, but all educators and education personnel are essentially also leaders, in the sense of being responsible for their respective duties. In an organization, one person and another person must have their respective expertise, so with the expertise they have, they are obliged to try their best so that the tasks and responsibilities given to them can be completed with the best results.

Second, Epistemology. Epistemology is a branch of philosophy that deals with the theory of science. This epistemology studies everything that is related to the nature of 
science, justification, and the rationality of belief. Epistemology and leadership can be interpreted as leadership knowledge, managerial knowledge and leadership knowledge that must be possessed by a leader. All of that can be done through formal (study/lecture) or non-formal (upgrading skill workshops, training, etc.). The leadership approach, leadership characteristics and leadership style are also included in the epistemological study side of this leadership field.

Third, axiology. In terms of axiology, it is one of the branches in philosophy that examines the issue of values in human life behavior, both moral and ethical and aesthetic values (Yusub, 2015). Axiology is a science that is used to test and integrate all the useful values of knowledge that is already owned in human life (Fithriani, 2017). The consequence of this axiological theory is to maintain and foster the knowledge or knowledge that has been obtained by internalizing it into each other's self and personality.

Axiology in leadership has very noble goals, including to create benefits for mankind and the universe (Solehudin, 2012). ). In the context of Islamic educational leadership, axiology can be applied to the real efforts of an educational leader to create benefits in the field of education. Conversely, a leader must not use his knowledge for evil purposes that can create damage on the earth, both individually and socially damaging to natural resources and the environment.

Philosophically, good leadership is one that is oriented in two directions simultaneously, namely towards organizational goals (goal-oriented), and also paying attention to the needs of members (member-oriented) (Poernomo, 2017). Among the manifestations of the principal's axiology is the best service provided to students and parents/guardians as consumers in the field of education. Also, positive compensation from the work process that has been carried out by educators and education personnel. Decent salary or welfare, as well as giving bonuses for teachers/employees who excel for them, including the real application of axiology in the world of educational leadership. This can be a motivation for teachers and employees to work better in the future.

Every leader must also have his philosophical model in running the organization or carrying out the leadership responsibilities that have been assigned to him. These philosophical figures might be a model for each leader in carrying out his leadership wheel. Three of the philosophical leadership models are: Plato's model which emphasizes 
the side of idealism; Aristotle's model that puts forward realistic aspects; and some lead like Machiavelli's model, whether it is right or wrong, the most important thing is that the goal of the organization can be achieved.

\section{Plato's Model}

Plato is a follower of the philosophical teachings of Socrates who lived 428-347 BC. The essence of Plato's philosophical teachings is the opinion that a human being in seeing everything must always depend on his mind and soul. Adherents to the teachings of the Plato model are people who live with high ideals. Idealists are people who think that everything is done and must always be realized perfectly. And all those who ignore that perfection must be confronted.

A leader who holds the principle of idealism is a leader who cannot be opposed. He will always defend his opinion and try to make it happen, whether it is possible or not. The law is mandatory. In fact, he will try to get rid of and ignore what I am different from him. This idealistic leadership style can be a good model if applied in organizations, including in educational institutions. With a note that the idealist leader is a leader who truly masters whatever field he is working on. This means that a leader with this idealism becomes dangerous if he does not master his field of work.

A leader must know his strengths and weaknesses to place himself, when to be idealistic, and when to give in to his idealism. This idealism model is relevant to Islam which also teaches this. In many verses of the Qur'an, Allah Almighty commands to be idealistic. That everything that is done in Islam is only oriented to one thing, namely heaven's reward. To reach heaven, a believer must also be idealistic, that is, he must be a godly person. This can at least be seen in QS. Al Baqarah [2] verses 183, 196, 197, 198. All of these verses teach to be an idealist, that is to be a pious person. And the ideal destination for a pious person is heaven (Hidayatullah, 2010)

\section{Aristotle's Model.}

Aristotle was the son of a court doctor who lived between 384-322 BC. His father died when he was a teenager. When he was 17 years old, he had studied Plato at the academy which he managed in Athens, until his teacher died in 347 BC. Initially, Aristotle was also familiar with Plato. But a few years after his teacher's death, he became a critic of his teacher's ideas. Until finally he had his philosophy, namely realism. This flow relies on a 
reality that can be seen with the five senses, then processes it with logic and thought.

A leader with Aristotle's model will find it easier to apply his leadership. Because he can be more realistic and able to adapt to the existing reality. He also became rational. Therefore, a realistic leader may be more acceptable to members of the organization. This is because a realist leader is more receptive to input from his subordinates. He will also be more creative and be able to take advantage of everything he faces. Even so, a realist leader must also stick to the applicable rules and ethics, otherwise, he can do negative things for realistic reasons or creativity.

This realistic model is in line with Islam, which does not want difficulties for its adherents, but on the contrary, it wants convenience. The concept of ijtihad (devoting knowledge to find out about the application of religious law) for benefit is among the relevant things to describe the realistic nature of Islam. That the teachings of Islam must not only be the same as the existing texts, but also be influenced by social realities (Yusuf, 2015). As exemplified by Rasulullah, who gave "leniency" punishment for people who breakfasting in the month of Ramadan without reason. Or also Umar bin Khatab who abolished the punishment of cutting off hands during his leadership for certain reasons.

\section{Machiavelli's Model}

His name was Niccolo Machiavelli (1469-1527). Initially, he was known as a political thinker from Italy. He also served as secretary to the Diplomatic Negotiation Council and the War Advisory Council in his country. So, Machiavelli's philosophical thoughts are also not far from the thoughts of a politician. That to obtain a power, consideration of aspects of ethics and morality is not needed in it, the most important thing is that he immediately succeeded in achieving the desired goal, effectively and efficiently.

In the author's opinion, this leader of the Machiavelli model is not recommended. Because he will rule out what is right, what is wrong. The most important thing in Machiavelli's leadership model is that his wish can be achieved immediately. So now we can easily find the slogan in the world of politics, that politics is something that justifies all kinds of methods to realize their desires. Meanwhile, Islam upholds morals, ethics, and morals, including politics (Zein, 2016). Good intentions or intentions should not be manifested in dirty ways. 


\section{The value of leadership in Islamic teachings}

In the perspective of Islamic teaching values, leadership, in general, has been exemplified by the Prophet Muhammad in a very perfect manner by referring to four important characteristics, namely: sidiq, amanah, tabligh, and fathonah. Sidiq means honest or trustworthy. Amanah means being responsible for what is assigned. Tabligh can be interpreted as communicative or able to communicate effectively. While fathonah which means smart. These four elements must be present in every human being who bears leadership, including leadership in the field of education.

\section{Sidiq/Honest}

This word is the opposite of the word kadzib or lie. Honesty is one of the main foundations and an absolute requirement that a leader must have (Nasri, 2019). Leaders who have an honest nature will certainly be loved by their members. Including in schools/madrasahs, principals who are honest with teachers and employees, who can also be trusted by students and parents/guardians, will automatically be loved by them. Conversely, if there is no honesty with the leader, then he will also be hated because of his dishonesty.

Because one thing that is judged by a leader is the suitability between the words spoken and the actions taken. An honest leader is a leader who can align what appears and is spoken from his mouth and what is hidden in the deepest space of his heart. Apart from being hated by fellow humans, dishonesty will certainly be hated by Allah Almighty. In a hadith narrated by Al Bukhari and Muslim it is stated that if a leader is dishonest and likes to deceive his subordinates, then Allah Almighty will forbid him to enter heaven (Nasri, 2019)

\section{Amanah/Trustworthy}

Almost the same as the points previously mentioned, the mandate also becomes the foundation for leadership holders. A trustworthy leader will not betray what is assigned to him. Since he had been entrusted with managing the affairs of the crowd, he would never betray him. In a very popular hadith narrated by Al Bukhari, it is stated that the nature of a true hypocrite is four things, and one of the characteristics of a hypocrite is that if given a mandate, then that person will betray (Tuasikal, 2020)

One that is managed by a school/madrasah principal is education funds, whether the funds are those received from parents/guardians of students or assistance/grants from the government in the form of school operational assistance (BOS) 
or allocation of grants other. There are also donations or donations from the public in general. Imagine if a person who has been entrusted with the position of school principal becomes an unsecured person, what happens is that the funds are misappropriated. And of course, this will bring harm to many people.

\section{Tabligh/Communicative}

Communicating effectively, or in a religious language called tabligh, is a trait that is also mandatory for a leader (Thaib, 2018). Because leaders are not people who interact with inanimate objects, but with humans who must be communicated with. Not only teachers/employees, but school principals are also required to be able to communicate well with parents/guardians and students. No less important, the principal must also maintain a good pattern of communication with the community in general, as well as to direct superiors in the education sector, whether related agencies or school management/organizing foundations.

A good leader is one who can always be open to anyone and does not close himself off from others. Information from schools must reach those in need. Regarding this effective communication, there are several verses of the Qur'an that discuss it, including An Nisa '[4]: 9, An Nisa' [4]: 63, Al Ahzab [33]: 32, Al Isra '[ 17]: 23, Al Isra '[17]: 28, and Thaha [20]: $43-44$ (Akbar, 2012). In An Nisa '[4] 63, for example, Allah Almighty instructs them to say "words that are left on their souls (qaulan baligha)", namely words that are right on the target, communicative, to the point, and easy to understand.

\section{Fathonah/Smart}

A leader is required to be able to solve all the problems and problems he faces in the organization. So it is inevitable, one of the mandatory skills that a leader must have is adequate intelligence. With the adequate intelligence that he has, he will certainly be able to help him solve the various problems that arise in running the organization. Do not let a leader, including in the world of education, experience frustration because he cannot find a solution to the problem he is facing.

In a hadith narrated by $\mathrm{Al}$ Bukhari, Rasulullah once said that if an affair is left to someone who is not an expert, what happens is destruction (Munawar, 2019). Allah Almighty in QS. Al Mujadilah [58] verse 11 also states that people who have knowledge 
will be exalted in the sight of Allah (Kementerian Agama RI, 2015). The intelligence of a leader does not have to indicate knowing everything and can always solve problems, but it can be in the form of intelligence managing his staff. The leader's intelligence in placing staff in the right place can help him to deal with problems that may arise in running the wheels of the organization.

\section{CONCLUSION}

Educational leadership is an effort and process to influence, mobilize and manage people who are in the educational environment, in the context of developing educational knowledge, as well as to realize the success of the education and learning process. All of these things are done to achieve educational goals effectively and efficiently which have been designed together in an educational organization.

Philosophically, leadership in education must have a strong foundation of thought to run the leadership wheel. Namely based on ontology, epistemology and axiology. These three things must be held by a leader so that he can carry out his leadership with comprehensive knowledge. Leadership models among them can be seen from several leading philosophers, including: Plato, Aristotle and Machiavelli. As well as the compatibility of the three models with Islamic values.

Islam through the Prophet Muhammad has also exemplified the leadership traits that must be possessed by every Muslim who holds the leadership stick, namely: honest, trustworthy, communicative and intelligent. In the language of religion these characteristics are referred to as: sidiq, amanah, tabligh and fathonah. It may be that he is not a perfect person regarding these four characteristics, but a leader should always try his best to have them all. This is what a Muslim leader should aim for in the world of education, because the foundation, values, and leadership competences are in Islamic teachings.

\section{REFERENCES}

Akbar F. (2012). Ayat dan Hadits Tentang Komunikasi Efektif.http://www.follyakbar.id /2012/11/ayat-dan-hadits-tentang-komunikasi.html/diakses30/10/2020jam 00.15 
Amirudin. (2013). Manajemen Pendidikan Islam Perspektif Filsafat Ilmu dan Al-Qur'an. Ijtimaiyya, 6(2), 19-45.

Amka. (2019). Filsafat Pendidikan. Sidoarjo: Nizamia Learning Center.

Anwar, M. (2017). Filsafat Pendidikan. Jakarta: Kencana.

Badu, S. Q, \& Djafri, N. (2017). Kepemimpinan Dan Perilaku Organisasi. Gorontalo: Ideas Publishing.

Bakar, Y. A. (2014). Filsafat Pendidikan Islam. Surabaya. Universitas Islam Negeri Sunan Ampel. https://doi.org/10.24252/ip.v6i2.5231

Djunaedi, A. F. (2005). Filosofi dan Etika Kepemimpinan dalam Islam. Al-Mawarid, 13(0), $54-66$.

Efendi, N. (2017). Islamic Educational Leadership: Praktik Kepemimpinan di Lembaga Pendidikan Islam. Yogyakarta: Kalimedia.

Fatonah, I. (2013). Kepemimpinan Pendidikan. Jurnal Tarbawiyah, 10(2), 109-125.

Fithriani. (2017). Implikasi Aksiologi Dalam Filsafat Pendidikan. Jurnal Intelektualita, $5(1), 83-92$.

Hidayatullah. (2010). Orang Mukmin itu Harus Idealis! http://www.ikadi.or.id/article/ orang-mukmin-itu-harus-idealis accessed on 12/12/2020 at 8.4 am

Hidayat, R. \& Nasution, H. S. (2016). Filsafat Pendidikan Islam: Membangun Konsep Dasar Pendidikan Islam. Medan: LPPPI.

Khamdani, P. (2014). Kepemimpinan dan Pendidikan Islam. Madaniyah, VII, 259-276.

Khatibah. (2011). Penelitian Kepustakaan. Iqra', 5(01), 36-39.

Kementerian Agama RI. (2015). Qur'an Hafalan dan Terjemahan. Jakarta: Penebit AlMahira.

Muhadjir, N. (1998). Metodologi Penelitian Kualitatif. Yogyakarta: Rake Sarasin.

Munawar, S. (2019). Kehancuran Pasti Terjadi, Jika Amanah Diurus oleh Bukan Ahlinya Retrieved from https://www.persis.or.id/kehancuran-pasti-terjadi-jika-amanahdiurus-oleh-bukan-ahlinya

Mushowwifin, M. S. (2020). Membangun Epistemologi Pendidikan Islam Melalui Kepemimpinan Spiritual: Suatu Telaah Diskursif. Al Yasini: Jurnal Kajian Dan Penelitian Keislaman Dan Pendidikan, 5(1), 319-336. https://doi.org/10.30762 /empirisma.v24i2.16 
Nasri, A. (2019). 4 Kriteria Pemimpin yang Berketuhanan. Retrieved from http://www. tablighmu.or.id/2019/01/4-kriteria-pemimpin-yang-berketuhanan.html/.

Nasri, A. (2019) Kepemimpinan Adalah Amanah. Retrieved from http://www.tablighmu.or.id/2019/07/kepemimpinan-adalah-amanah.html

Nursikin, M. (2016). Aliran-aliran Filsafat Pendidikan dan Implementasinya dalam Pengembangan Kurikulum Pendidikan Islam. Attarbiyah: Journal of Islamic Culture and Education, 1(2), 303-334. https://doi.org/10.18326/attarbiyah. v1i2.303-334

Poernomo, S. H. (2017). Filsafat Kepemimpinan. Retrieved from: https://forumkeadilan. com/2017/09/filsafat-kepemimpinan/.

Prasetyo, H. (2017). Analisis Gaya Kepemimpinan Kepala Sekolah dalam Meningkatkan Kinerja Guru. Naskah Publikasi. Universitas Muhammadiyah Surakarta. http://eprints.ums.ac.id/53908/13/NASPUB.pdf

Priyono. \& Marnis. (2008). Manajemen Sumber Daya Manusia. Sidoarjo: Zifatama Publisher.

Purwanto, N. A. (2019). Kepemimpinan Pendidikan, Kepala Sekolah sebagai Manager dan Leader. Yogyakarta. Interlude.

Pusat Pembinaan, Pendidikan dan Pelatihan. (2019). Tim Efektif. Modul PPJFP, Cibinong: Lembaga Ilmu Pengetahuan Indonesia (LIPI).

Riyadiningsih, H. (2016). Teori Kepemimpinan: Sebuah Tinjauan dari Perspektif Filsafat Ilmu. Segmen: Jurnal Manajemen Bisnis, 12(1).

Rukiyati. \& Purwastuti, L. A. (2015). Mengenal Filsafat Pendidikan. Yogyakarta: UNY Press. Sari, M. \& Asmendri. (2020). Penelitian Kepustakaan (Library Research) dalam Penelitian Pendidikan IPA. Natural Science: Jurnal Penelitian Bidang IPA dan Pendidikan IPA, 6(1), 41-53. DOI: 10.15548/nsc.v6i1.1555.

Siyoto, D. S. (2015). Dasar Metodologi Penelitian. Yogyakarta: Literasi Media Publishing. Solehudin, E. (2012). Filsafat Ilmu Menurut Al-Qur'an. Islamica: Jurnal Studi Keislaman, 6(2), 263-276. https://doi.org/10.15642/islamica.2012.6.2.263-276 Srinadila, R. (2019). Kepemimpinan Pendidikan. 1-5. https://doi.org/10.31227/osf.io /6yqxm.

Sukamto. (1999). Kepemimpinan Kyai dalam Pesantren. Jakarta: LP3ES. 
Syafaruddin. \& Asrul. (2015). Kepemimpinan Pendidikan Kontemporer. Bandung: Citapusaka Media.

Thaib, M. I. (2016). Kepemimpinan Pendidikan dalam Islam. Jurnal Intelektualita, 4(1), $66-95$.

Tuasikal, M. A. (2020). Lima Ciri Munafik. Retrieved from https://rumaysho.com/ 25293-lima-ciri-munafik-hadits-jamiul-ulum-wal-hikam-48.html

Wattimena, R. A. A. (2012). Menjadi Pemimpin Sejati: Sebuah Refleksi Lintas Ilmu. Jakarta: Evolitera.

Yaniawati, P. \& Indrawan, R. (2014). Metodologi Penelitian: Kuantitatif, Kualitatif, dan Campuran untuk Manajemen, Pembangunan, dan Pendidikan. Bandung: PT Refika Aditama.

Yusnadi. (2016). Sifat Kepemimpinan Pendidikan dalam Perspektif Islam. Tarbiyah Islamiyah, 6(1), 52-61.

Yusub, F. H. (2015). Pemikiran Fazlur Rahman Tentang Aksiologi dan Implikasinya Terhadap Perkembangan Pendidikan Islam. Thesis. Universitas Islam Negeri Maulana Malik Ibrahim Malang.

Yusuf, A. S. (2015). Akar Pemikiran Realisme dalam Hukum Islam. Asy-Syariah, 17(1), 180-187. DOI: https://doi.org/10.15575/as.v17i1.637.

Zein, F. M. (2016). Kritik Konsep Politik Machiavelli dalam Perspektif Etika Politik Islam (Perbandingan dengan Teori Etika Politik Al Mawardi). Mahkamah: Jurnal Ilmu Hukum dan Hukum Islam, 1(2), 489-507. 